\title{
Characterization of Yeast Vps33p, a Protein Required for Vacuolar Protein Sorting and Vacuole Biogenesis
}

\author{
LOIS M. BANTA, THOMAS A. VIDA, PAUL K. HERMAN, AND SCOTT D. EMR* \\ Division of Biology, California Institute of Technology, Pasadena, California 91125
}

Received 27 March 1990/Accepted 15 June 1990

\begin{abstract}
vps33 mutants missort and secrete multiple vacuolar hydrolases and exhibit extreme defects in vacuolar morphology. Toward a molecular understanding of the role of the VPS33 gene in vacuole biogenesis, we have cloned this gene from a yeast genomic library by complementation of a temperature-sensitive vps33 mutation. Gene disruption demonstrated that VPS33 was not essential but was required for growth at high temperatures. At the permissive temperature, vps33 null mutants exhibited defects in vacuolar protein localization and vacuole morphology similar to those seen in most of the original mutant alleles. Sequence analysis revealed a putative open reading frame sufficient to encode a protein of 691 amino acids. Hydropathy analysis indicated that the deduced product of the VPS33 gene is generally hydrophilic, contains no obvious signal sequence or transmembrane domains, and is therefore unlikely to enter the secretory pathway. Polyclonal antisera raised against TrpE-Vps33 fusion proteins recognized a protein in yeast cells of the expected molecular weight, $\sim 75,000$. In cell fractionation studies, Vps33p behaved as a cytosolic protein. The predicted VPS33 gene product possessed sequence similarity with a number of ATPases and ATP-binding proteins specifically in their ATP-binding domains. One vps33 temperature-sensitive mutant contained a missense mutation near this region of sequence similarity; the mutation resulted in a Leu-646 $\rightarrow$ Pro substitution in Vps33p. This temperaturesensitive mutant strain contained normal vacuoles at the permissive temperature but lacked vacuoles specifically in the bud at the nonpermissive temperature. Our data suggest that Vps33p acts in the cytoplasm to facilitate Golgi-to-vacuole protein delivery. We propose that as a consequence of the vps33 protein-sorting defects, abnormalities in vacuolar morphology and vacuole assembly result.
\end{abstract}

Eucaryotic cells contain a number of distinct membraneenclosed organelles whose function and morphology are defined largely by the unique set of proteins residing within them. Thus, mutations that disrupt the accurate sorting of proteins to their correct intracellular locations might also affect the assembly and morphology of the target organelle. Conversely, abnormalities in organelle biogenesis may be manifest as protein trafficking or delivery defects.

In the yeast Saccharomyces cerevisiae, proteins destined for the lysosomelike vacuole traverse the secretory pathway en route to the vacuole. Soluble vacuolar proteins such as carboxypeptidase $\mathrm{Y}(\mathrm{CPY})$ and proteinase $\mathrm{A}(\mathrm{PrA})$ are synthesized as inactive precursors; upon delivery to the vacuole, these proenzymes undergo proteolytic processing to generate the mature active enzymes $(14,15,26,49)$. We and others have recently isolated a number of mutants that exhibit defects in the proper localization and processing of multiple vacuolar hydrolases $(1,40,42,43)$. These vacuolar protein sorting, or vps, mutants define more than $40 \mathrm{com}-$ plementation groups. Morphological studies using both light and electron microscopy have revealed at least three distinct groups of vps mutants (2). The majority of the vps mutants (called class A vps mutants) contain morphologically wildtype (wt) vacuoles. A second class of mutants, class $B$, is characterized by an altered morphology in which the vacuole is highly fragmented. Mutants in four vps complementation groups exhibit the most extreme abnormalities in vacuole morphology. Electron microscopic analysis has revealed that these cells accumulate many small vesicles but lack any compartment that resembles a wt vacuole. This morphology has been designated class $C(2)$.

\footnotetext{
* Corresponding author.
}

The class $\mathrm{C}$ vps mutants exhibit extreme defects in the sorting and processing of soluble vacuolar proteins. In these strains, the Golgi-modified forms of CPY, PrA, and proteinase $B$ accumulate and are secreted. Little or no mature forms of these vacuolar enzymes can be detected in these mutants. Unlike other vps mutants, these class $\mathrm{C}$ strains also mislocalize as much as $50 \%$ of the activity of a vacuolar membrane enzyme, $\alpha$-mannosidase (40). The class $C$ vps mutants exhibit other genetically linked phenotypic defects, including temperature-sensitive (Ts) growth and sensitivity to osmotic stress. However, nonvacuolar functions such as secretion and microtubule assembly, as well as nuclear and mitochondrial structure, appear to be unaffected in these strains $(2,40)$.

In an effort to understand the molecular basis for the phenotypic defects exhibited by the class $\mathrm{C} v p s$ mutants, we have examined in more detail the seven mutants comprising one of these class $\mathrm{C}$ complementation groups, vps33. We report here the cloning of the VPS33 gene. This gene is not essential but is required for growth at $37^{\circ} \mathrm{C}$. The predicted VPS33 gene product is a relatively hydrophilic protein of $\sim 75$ kilodaltons $(\mathrm{kDa})$ that shares sequence similarity with a number of ATP-binding proteins. Cell fractionation studies indicate that Vps33p is soluble. We suggest that the VPS33 gene product acts in the cytoplasm to facilitate Golgi-tovacuole trafficking, thereby promoting vacuole assembly.

\section{MATERIALS AND METHODS}

Strains and media. Escherichia coli $\mathrm{MC} 1061 \mathrm{FF}^{-}$araD139 $\Delta($ araABOIC-leu $) 7679 \Delta$ lacX74 galU galK rpsL hsdR strA] (4), JM101 [supE thi $\Delta$ (lac-proAB) $\left(\mathrm{F}^{\prime}\right.$ traD36 proAB lacl ${ }^{q} Z$ M15)] (27), and DH1 [ $\mathrm{F}^{-}$endAl hsdRI7 ( $\left.\mathrm{rK}^{-} \mathrm{mK}^{+}\right)$supE44 thi-1 recAl gyrA96 relAl?] (13) were used for cloning and TrpE-Vps33 fusion protein production. E. coli JF1754 (hsdR 
metB leuB hisB lac gal) (25) was used in screening plasmids pLB33-313 and pLB33-317. S. cerevisiae parental strains

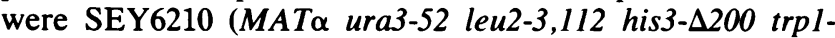
$\Delta 901$ lys2-801 suc2- $\Delta$ 9) and SEY6211 (MATa ura3-52 leu2-

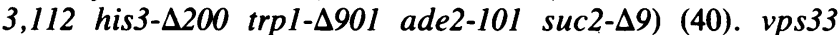
mutant strains SEY33-2, SEY33-4, and SEY33-5 are isogenic with SEY6210 and carry the vps33-2, vps33-4, and vps33-5 mutations, respectively. SEY33-7, carrying the vps33-7 allele, is isogenic with SEY6211. LBY317 carries a vps33 null mutation and was derived from SEY6210 (see below). Bacterial strains were grown on standard media (28). Yeast strains were grown on standard yeast extract-peptonedextrose (YPD) or synthetic dextrose (SD) (synthetic minimal, supplemented as necessary) medium (47).

Materials. Restriction enzymes, T4 DNA ligase, Klenow enzyme, and polyacrylamide gel electrophoresis supplies were purchased from Boehringer Mannheim Biochemicals (Indianapolis, Ind.). Mung bean nuclease and exonuclease III were the products of New England BioLabs (Beverly, Mass.). 5-Fluoroorotic acid was purchased from PCR, Inc. (Gainesville, Fla.). Isopropyl- $\beta$-D-thiogalactoside (IPTG), 5-bromo-4-chloro-3-indolyl- $\beta$-D-galactoside (X-Gal), and Sequenase DNA sequencing kit were purchased from United States Biochemical Corp. (Cleveland, Ohio). Deoxynucleotides and Miniprep Kit Plus were the products of Pharmacia, Inc. (Piscataway, N.J.). Tran ${ }^{35}$ S label was the product of ICN Radiochemicals (Irvine, Calif.). Multiprime DNA labeling system, $\left[\alpha-{ }^{35}\right.$ S $] \mathrm{dATP}$, and $\left[\alpha-{ }^{32} \mathrm{P}\right] \mathrm{dCTP}$ were purchased from Amersham Corp. (Arlington Heights, Ill.). Nitrocellulose and the Elutrap Electro-Separation Chamber were the products of Schleicher \& Schuell, Inc. (Keene, N.H.) and were used as instructed by the manufacturer. Autofluor was purchased from National Diagnostics (Manville, N.J.), Freund complete and incomplete adjuvants were purchased from GIBCO Laboratories (Grand Island, N.Y.), and 5(6)-carboxy-2',7'-dichlorofluorescein diacetate (CD CFDA) was purchased from Molecular Probes, Inc. (Eugene, Ore.). Antiserum against CPY was from Klionsky et al. (19). All other chemicals were purchased from Sigma Chemical Co. (St. Louis, Mo.) or other standard sources.

Genetic and DNA manipulations. Standard recombinant DNA techniques were performed as described previously (23). Genetic crosses, sporulation of diploids, and dissection of tetrads were performed according to Sherman et al. (47). Yeast transformations were done by the lithium acetate method of Ito et al. (16) in the presence of $10 \mu \mathrm{g}$ of denatured salmon sperm carrier DNA.

Chromosomal DNA was isolated and Southern analysis was performed (23), using DNA fragments containing either the HIS3 gene or the VPS33 gene as a probe. Northern (RNA) analysis (23) was carried out by using the 1.1-kilobase (kb) ClaI-SmaI VPS33 fragment as a probe, and total RNA was isolated as described by Eakle et al. (9). DNA probes were labeled by using the Amersham Multiprime DNA labeling system.

Vectors and plasmid constructions. $E$. coli plasmids pBluescript KS (+) and (-) are described in the Stratagene (La Jolla, Calif.) catalog. The yeast-integrating vector PPHYI10 (TRPI, selectable marker) and the $E$. coli-yeast shuttle vectors pPHYC16 and pPHYC18 (CEN4 ARSI URA3) will be described elsewhere (P. Herman, unpublished data). The $E$. coli-yeast shuttle vector pSEY18 is a derivative of pSEY8 (11) in which the pUC8 polylinker has been replaced with the polylinker of pUC18. The HIS3 gene was isolated as a 1.75-kb Bam HI fragment from a plasmid kindly provided by E. Phizicky. The pATH vectors used in the TrpE-Vps33 fusion protein production have been previously described (6).

The 3.7-kb SalI-XbaI fragment of VPS33 (see Fig. 2B) was subcloned into the pBluescript $\mathrm{KS}(+)$ and $(-)$ vectors to generate pLB33-211 and pLB33-212, respectively. Plasmid pLB33-102, used in the integrative mapping experiment, was constructed by cloning the 5.3-kb SalI-PvuII fragment shown in Fig. 2B into the SalI-SmaI sites of the yeastintegrating vector pPHYI10. Construction of pLB33-313, used in the disruption of VPS33, was achieved by digesting plasmid pLB33-212 with EcoRI to remove the region shown in Fig. 2C, gel purifying the resulting linear DNA away from the two EcoRI fragments, blunting the ends with Klenow enzyme, and inserting the HIS 3 gene as a blunted BamHI fragment. Recombinant plasmids were selected directly for the presence of the HIS 3 gene in the hisB bacterial strain JF1754 (25) on M63 minimal medium lacking histidine (28). In a similar manner, the 2.1-kb HindIII-SmaI fragment indicated in Fig. 2C was removed and replaced with the HIS3 gene to generate plasmid pLB33-317. Plasmid pLB33221 , carrying the VPS33 gene on a multicopy $(2 \mu \mathrm{m})$ vector, was constructed by excising the $S a l I-X b a I$ fragment from pLB33-21 (see below) as a SalI-SacI fragment (using the SacI site in the polylinker) and ligating it to the SalI-SacI sites of the $2 \mu \mathrm{m}$ vector pSEY18. A truncated form of $V P S 33$, encoding all but the carboxy-terminal 56 amino acids (aa) of Vps33p, was constructed by subcloning the $2.7-\mathrm{kb}$ PstI fragment (Fig. 2C) into the PstI site of pBluescript KS (-) and then moving this fragment (as a BamHI-SalI fragment) into the corresponding sites in the $E$. coli-yeast shuttle vector pPHYC18 to construct pLB33-304. Plasmid pLB33162 was constructed by cloning the $3.7-\mathrm{kb} S a l I-X b a I$ fragment into the $E$. coli-yeast shuttle vector pPHYC16.

Cloning and sequence analysis of VPS33. Yeast strain SEY33-2 was grown in YPD to an optical density at $600 \mathrm{~nm}$ of 0.5 to 1.0 and transformed at room temperature as described previously (16) with a yeast genomic library constructed by Rose et al. (41). The library contains inserts from a partial Sau3A digestion of $S$. cerevisiae genomic DNA carried on the $E$. coli-yeast shuttle vector $\mathrm{YCp} 50$ (CEN4 ARS1 URA3). Transformants were selected on SD lacking uracil at $25^{\circ} \mathrm{C}$ and replicated to YPD plates, which were incubated at the restrictive temperature, $37^{\circ} \mathrm{C}$. Temperature-resistant transformants were picked, restreaked, and cured of the plasmid by incubation on 5-fluoroorotic acid plates (3). Complementing plasmid DNA (pLB33-6) was isolated and propagated in the bacterial strain MC1061. Plasmid DNA was transformed into SEY33-2, SEY33-5, and SEY33-7, and transformants were tested for temperature sensitivity (growth on YPD at $37^{\circ} \mathrm{C}$ ), osmotic sensitivity (growth on YPD containing $1.5 \mathrm{M} \mathrm{NaCl}$ ) (2), vacuolar protein sorting (40), and vacuole morphology (see below). The plasmid DNA was also subjected to restriction enzyme analysis. The restriction fragments shown in Fig. 2B were isolated from pLB33-6 and subcloned into the appropriate restriction sites within the polylinker of the $E$. coli-yeast shuttle vector pPHYC18 to generate plasmids pLB33-20 through pLB33-24. Plasmid pLB33-21 was digested with SalI and KpnI, and exonuclease III was used (50) to generate deletions from the SalI end of the insert. The ends were blunted by using mung bean nuclease and Klenow enzyme and religated to generate deletion plasmids pLB33-41 and pLB33-42. The approximate endpoints of these deletions were determined by restriction analysis.

Two sets of nested deletion templates for sequencing were generated by deleting from the SalI end of the insert in 
pLB33-212 and the $X b a I$ end of the insert in pLB33-211, using exonuclease III (50). Deletions were also generated from the internal SmaI site in pLB33-211, and additional templates were constructed by cloning the 0.5-kb EcoRI fragment, the 1.5-kb ClaI-XbaI fragment, the 0.4-kb PstI$X b a I$ fragment, the 2.7-kb PstI fragment, and the 1.4-kb HindIII fragment (see Fig. 2C) into pBluescript $\mathrm{KS}(-)$. Single-stranded template DNA was prepared from these constructs (50) after infection with the helper bacteriophage VCSM13 (Stratagene), and synthetic primers corresponding to the $\mathrm{T} 3$ or $\mathrm{T} 7$ promoter sequence were prepared by DNA synthesizer. The sequence of both strands of VPS33 was determined by the dideoxy-chain termination method (46).

DNA sequence and hydropathy analyses (21) were done by using a program written by $\mathrm{K}$. Eakle (unpublished). A DNA homology search was performed by using the TFASTA algorithm, the GENEMBL data bank, and the University of Wisconsin Genetics Computer Group sequence analysis software package. Additional homology searches using the GenBank, EMBL, NBRF, and SWISSPROT protein data bases and the FASTA program (36) were done on BIONET.

Mapping and rescue of the vps33-4(Ts) allele. Recombinational rescue analysis was carried out on SEY33-4 carrying plasmid pLB33-23 or pLB33-24, described above. Additional plasmids were constructed by cloning the 2.1-kb SmaI-PvuII fragment, the 2.3-kb SphI-PvuII fragment, and the 0.7-kb HindIII-SmaI fragment (see Fig. 2B and C) into the appropriate restriction sites of pSEY18. In each case, the plasmid was transformed into SEY33-4 and the frequency of temperature-resistant recombinants was scored.

The vps33-4(Ts) mutation was rescued by using doublestranded gap repair (33) as follows. The complete VPS33 gene was subcloned as a 5.3-kb PvuII-SalI fragment into the $E$. coli-yeast shuttle vector pPHYC16, and the resulting plasmid (pLB33-160) was digested with XbaI and SmaI to generate a gapped linear plasmid. The linear plasmid was gel purified away from the 0.5-kb SmaI-XbaI fragment. SEY334 was transformed with this plasmid, and Ura ${ }^{+}$transformants were scored for temperature sensitivity. Plasmid DNA (designated pLB33-161) carrying the rescued vps334 (Ts) allele was purified. The SmaI-XbaI fragment carrying the mutation was isolated and subcloned into pBluescript $\mathrm{KS}$ (-). Double-stranded DNA was isolated by using the Pharmacia Miniprep Kit Plus and sequenced. The VPS33 gene carrying the vps33-4(Ts) mutation was excised from pLB33161 as a SalI-SacI fragment (using the SacI site in the polylinker) and cloned into the $2 \mu \mathrm{m}$ vector pSEY18 to generate pLB33-271.

Antibody production. trpE-VPS33 gene fusions were constructed by using the two fragments of the VPS33 gene depicted in Fig. 2C. The 0.7-kb HindIII-SmaI fragment was isolated from pLB33-21, blunted by using Klenow enzyme, and ligated to the blunted SalI site of the pATH3 vector to generate an in-frame fusion encoding aa 379 to 608 of Vps33p. The 0.5-kb EcoRI fragment was isolated, blunted as described above, and ligated into the $S m a I$ site of the pATH 2 vector to generate an in-frame fusion encoding aa 140 to 303 of $\mathrm{Vps} 33 \mathrm{p}$. Individual transformants were purified, and the presence and orientation of the VPS33 sequence was confirmed by restriction analysis. Bacterial strains carrying candidate fusion constructs were assayed for the production of fusion protein (48). Whole-cell lysates and insoluble fractions were prepared basically as described by Kleid et al. (18) (except that $2 \%$ Triton X-100 was used rather than $0.2 \%$ Nonidet $\mathrm{P}-40$ ) and subjected to sodium dodecyl sulfate-9\% polyacrylamide gel electrophoresis (22). Inducible fusion proteins of the expected molecular sizes $(62$ and $55 \mathrm{kDa}$ ) were the predominant bands visualized in the insoluble fractions upon Coomassie staining. The bands containing the fusion proteins were excised from Coomassiestained preparative gels and electroluted from the gel slices by using a Schleicher \& Schuell Electro-Separation Chamber. Approximately $175 \mu \mathrm{g}$ of each purified fusion protein, emulsified with Freund complete adjuvant, was injected intramuscularly and subcutaneously into a young male New Zealand White rabbit. After 4 weeks, the rabbit was boosted with $25 \mu \mathrm{g}$ of each fusion protein in an emulsion with Freund incomplete adjuvant. Antisera were screened by immunoprecipitation. A titration curve was generated for these antisera to determine the amount needed for a quantitative recovery of overproduced levels of Vps33p.

Immunoprecipitation. Cells were grown in SD medium (47) supplemented with the appropriate amino acids. Whole cells (1.5 U at an optical density at $600 \mathrm{~nm}$ of 1.0 ) were collected by centrifugation. The cells were resuspended in $0.5 \mathrm{ml}$ of the same medium, and $125 \mu \mathrm{Ci}$ of $\mathrm{Tran}^{35} \mathrm{~S}$ label was added. The cells were labeled for $20 \mathrm{~min}$ with shaking at the appropriate temperature. A 30 -min chase was initiated by the addition of methionine to a final concentration of $4 \mathrm{mM}$. The chase was terminated, and cells were lysed and subjected to a single round of immunoprecipitation, using antiserum specific for Vps33p or CPY as described previously $(9,19)$.

Cell fractionation. Cells were grown in SD medium (47) as described above. Six units of cells at an optical density at 600 $\mathrm{nm}$ of 1.0 were harvested by centrifugation and spheroplasted in the same medium as described previously (40). Spheroplasts were labeled and chased as described above. All subsequent manipulations were performed at $4^{\circ} \mathrm{C}$. Labeled spheroplasts were pelleted at $1,200 \times g$ for $2 \mathrm{~min}$. The spheroplasts were suspended in $1 \mathrm{ml}$ of lysis buffer $(50 \mathrm{mM}$ Tris chloride [pH 7.5], $1 \mathrm{mM}$ EDTA, $5 \mathrm{mM} \mathrm{MgCl}_{2}, 1 \mathrm{mM}$ phenylmethylsulfonyl fluoride, $1 \mu \mathrm{M}$ leupeptin, $1 \mathrm{mM}$ sodium azide, $0.125 \mathrm{mg}$ of $\alpha_{2}$-macroglobulin per $\mathrm{ml}$ ) with various concentrations of $\mathrm{KCl}$ as indicated and vortexed for $30 \mathrm{~s}$. In some experiments, the lysis buffer also contained 0.3 M mannitol or $0.8 \mathrm{M}$ sorbitol for partial osmotic support (29, 45). Unlysed spheroplasts were removed by centrifugation at $500 \times g$ for 2 min and subjected to a second round of lysis. Unlysed spheroplasts were removed as before, and the lysates were pooled and immediately centrifuged at 100,000 $\times g$ for $90 \mathrm{~min}$. The pellet was rinsed gently with $1 \mathrm{ml}$ of lysis buffer and suspended in $1 \mathrm{ml}$ of $0.5 \%$ sodium dodecyl sulfate. Supernatant and pellet fractions were precipitated with trichloroacetic acid (5\% final concentration) and immunoprecipitated.

Fluorescent labeling of cells and microscopy. Cells were grown in YPD, labeled with CDCFDA or fluorescein isothiocyanate (FITC), and observed as described previously (2, 37, 38).

GenBank accession number. The GenBank accession number for the sequence reported in this paper is M34638.

\section{RESULTS}

Cloning and genetic analysis of the VPS33 gene. The VPS33 gene was cloned by complementation of the vps33-2(Ts) mutation (in the Ura3 ${ }^{-}$strain SEY33-2) with a yeast genomic library carried on the single-copy vector YCp50 (41). Among $11,000 \mathrm{Ura}^{+}$transformants, 7 were temperature resistant. Upon curing of these transformants of the plasmid, five 


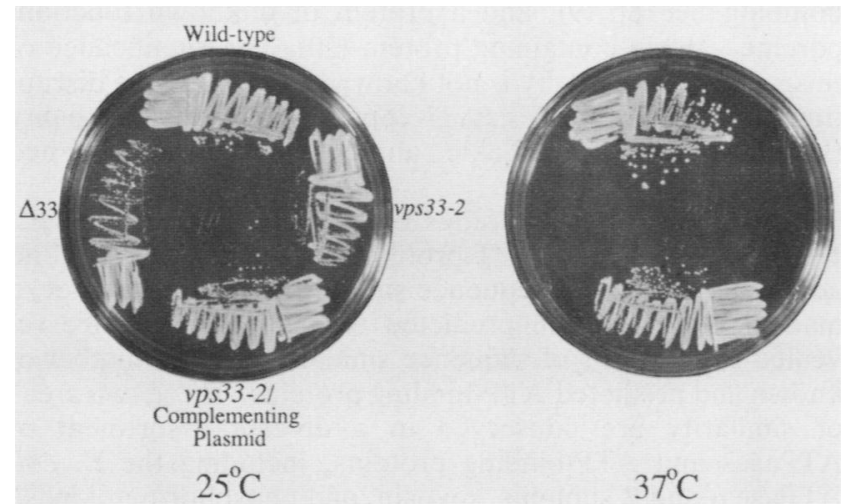

FIG. 1. Complementation of vps33-2(Ts) by the cloned VPS33 gene. The parental strain SEY6210, the SEY33-2 mutant strain without and with the complementing plasmid pLB33-21, and the isogenic vps33 null mutant LBY317 were streaked on YPD solid media and incubated at 25 or $37^{\circ} \mathrm{C}$, as indicated. remained temperature resistant, indicating that the temperature resistance was not dependent on the presence of the plasmid. The remaining two transformants were temperature sensitive when cured, suggesting that the temperature-resistant phenotype was indeed conferred by the plasmid. Restriction analysis of the purified plasmid from these two transformants revealed that the two complementing plasmids contained identical inserts. Retransformation of SEY33-2 and two other vps33 strains demonstrated that this plasmid, designated pLB33-6, complemented all of the phenotypes associated with the vps 33 mutations, including temperature sensitivity (Fig. 1), mislocalization of vacuolar proteins (see Fig. 5), osmotic sensitivity, and the defect in vacuole biogenesis (data not shown).

A restriction map of the 12-kb insert in pLB33-6 is shown in Fig. 2A. Subcloning and complementation analysis (Fig. 2B) indicated that the complementing activity resided on a 3.7-kb SalI-XbaI fragment. Removal of as much as 1,000 base pairs (bp) from the Sall end, using exonuclease III, did not destroy the ability to complement.

To confirm that this complementing ability was not due to suppression by another gene, we carried out integrative

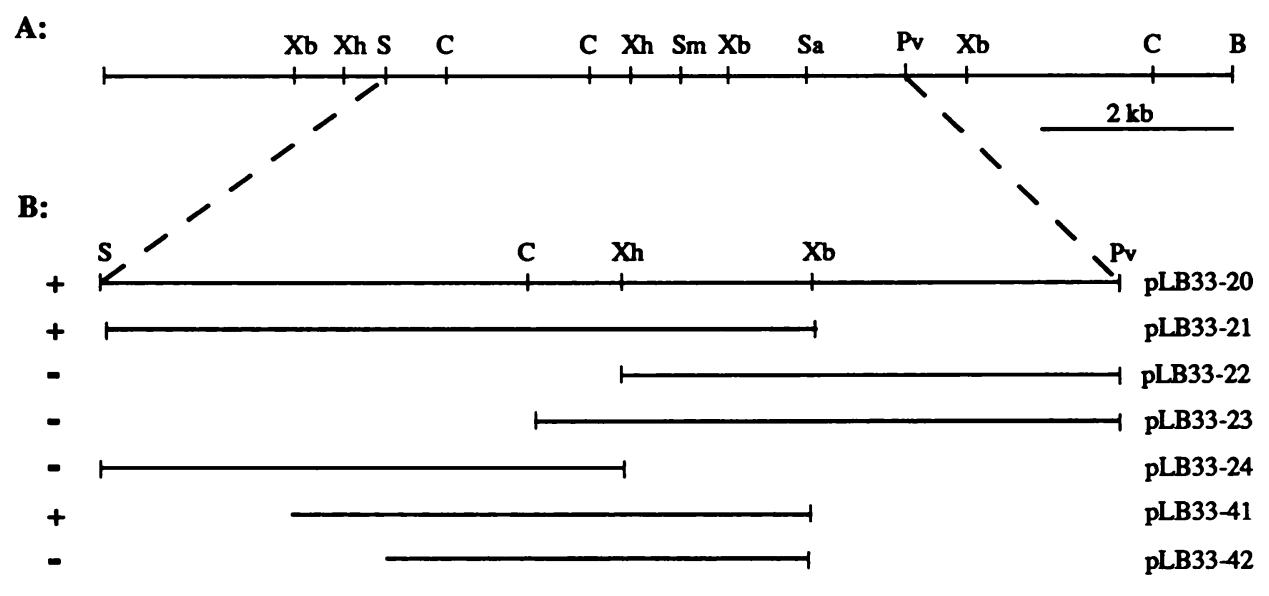

C:

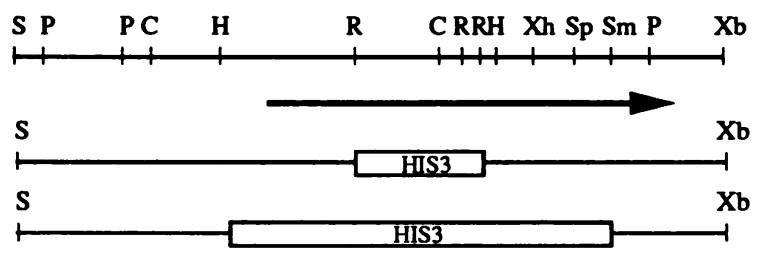

Open Reading Frame
pLB33-313 $(\Delta 33)$
pLB33-317 $(\Delta 33)$
Fragments Used in
Antibody Production

FIG. 2. (A) Restriction map of the entire 12-kb VPS33 complementing clone. Restriction site abbreviations: B, Bam HI; C, ClaI; Pv, PvuII; S, SalI; Sa, SacI; Sm, SmaI; Xb, XbaI; Xh, XhoI. (B) Complementation analysis of the VPS33 subclones. Restriction fragments were cloned into pPHYC18 (CEN4 ARS1 URA3) to generate pLB33-20, pLB33-21, pLB33-22, pLB33-23, and pLB33-24. Plasmids pLB33-41 and pLB33-42 were the result of exonuclease III deletions from the SalI end of the complementing fragment in pLB33-21 to yield the endpoints shown. The plasmids were transformed into SEY33-7, and Ura ${ }^{+}$transformants were tested for growth at $37^{\circ} \mathrm{C}$. Vacuole morphology, as assessed by staining with CDCFDA (see Materials and Methods), was also scored. Symbols: + , the transformants were temperature resistant and exhibited class $\mathrm{A}(\mathrm{wt})$ vacuole morphology; - , the transformants had a temperature-sensitive class $\mathrm{C}$ phenotype. (C) Fragments used for antibody production and gene disruption. The position of the ORF as determined by sequencing is shown. Plasmids pLB33-313 and pLB33-317, in which the HIS3 gene replaced the indicated portions of VPS33, were used to generate vps33 null mutants as described in the text. , Fragments used to generate in-frame trpE-VPS33 gene fusions. The encoded hybrid proteins were used in antibody production as described in Materials and Methods. Additional restriction site abbreviations: H, HindIII; P, PstI; R, EcoRI; Sp, SphI. 
mapping studies with the clone. The complementing 5.3-kb SalI-PvuII fragment (Fig. 2B) was cloned into the integrating vector PPHYI10, which carries the selectable marker TRPI. The resulting plasmid was linearized at the internal $X h o I$ site to facilitate homologous recombination (32) and was transformed into a Trp1- ${ }^{-}$strain harboring the vps33-7(Ts) mutation. $\operatorname{Trp}^{+}$temperature-resistant transformants were crossed to the Trp1 ${ }^{-} V P S^{+}$parental strain SEY6210. Tetrad analysis of the sporulated diploids showed the expected $2: 2 \operatorname{Trp}^{+}$: $\mathrm{Trp}^{-}$segregation pattern; all four spores in each of the 12 asci analyzed were temperature resistant and exhibited wt vacuolar morphology. Further analysis of 190 random spores also failed to uncover any temperature-sensitive segregants, whereas the $\operatorname{Trp}^{+}: \operatorname{Trp}^{-}$phenotype segregated 97:93. These observations demonstrated that the complementing clone is tightly linked to the vps33 mutant locus.

The complementing SalI-XbaI fragment was also cloned into the $2 \mu \mathrm{m}$ (multicopy) vector pSEY18 to generate the plasmid pLB33-221. Yeast transformants harboring this plasmid overproduced the VPS33 gene product $\sim 20$-fold (see below). Transformation of SEY33-7 or wt strains with pLB33-221 resulted in a $\mathrm{Vps}^{+}$phenotype, indicating that severalfold overproduction of the VPS33 gene product is not detrimental to otherwise wt cells. We also transformed pLB33-221 into a representative allele of each of the other three class $\mathrm{C}$ complementation groups, vps $11,-16$, and -18 . In no case did the plasmid suppress any of the defects associated with these mutations; thus, overproduction of Vps33p appears unable to rescue any of these phenotypically similar mutants.

VPS33 sequence analysis. The nucleotide sequence of VPS33 was determined by sequencing a series of nested exonuclease III-generated deletion templates by the dideoxynucleotide-chain termination method (46). The DNA sequence (Fig. 3) contains a single long open reading frame (ORF) of $2,073 \mathrm{bp}$, with the potential to encode a protein of 691 aa. Examination of the 5 ' noncoding sequences revealed a possible transcription initiation sequence, TATATTAA (31), at position -157 relative to the putative translational initiation codon. A consensus sequence for transcription termination, TAG....TAGT....TTTT (31) (underlined in Fig. 3), is found 147 bp downstream of the ORF stop codon TAA. Northern analysis was performed, using an internal fragment of VPS33 as a probe to identify the VPS33 transcript. Consistent with the ORF size predicted from the DNA sequence, a single RNA species of $2.2 \mathrm{~kb}$ was detected (data not shown).

The sequence of the predicted VPS33 gene product was subjected to hydropathy analysis according to the model of Kyte and Doolittle (21). The predicted Vps33 polypeptide is hydrophilic ( $26 \%$ charged amino acids), with no apparent hydrophobic domains that could span a membrane or function as a signal sequence (data not shown). A search for sequence homology using the GENEMBL data bank and the TFASTA algorithm (36) revealed that the $3^{\prime}$ end of the VPS33 gene (nucleotides 2307 to 2695) is identical to the sequence upstream of the yeast $C O X 8$ gene, which encodes the cytochrome $c$ oxidase subunit VIII. Furthermore, the published sequence of the $C O X 8$ gene contains a short ORF $5^{\prime}$ of the $C O X 8$ coding region which corresponds to the last 55 codons of the VPS33 ORF (35). From these results, we conclude that the VPS33 gene lies next to the COX8 gene in the yeast genome. Sequence analysis also revealed an ORF $5^{\prime}$ of the VPS33 gene. An interesting sequence similarity was noted between this ORF and three other proteins: the mammalian $N$-ethylmaleimide-sensitive factor (56), its yeast homolog Sec18p (9), and a protein of unknown function, porcine valosin-containing protein (20). The significance of this sequence similarity is not known; however, gene disruption of the ORF 5' of VPS33 appears to result in lethality (L. M. Banta, K. A. Eakle, and S. D. Emr, unpublished observations).

Further homology searches using the GenBank, EMBL, NBRF, and SWISS-PROT protein data bases uncovered no additional significant sequence similarities (36). However, a manual search of the predicted amino acid sequence revealed two regions of sequence similarity with a number of known and predicted ATP-binding proteins. These two areas of similarity are conserved in a diverse assortment of ATPases and ATP-binding proteins, including the $E$. coli ATPase $\alpha$ and $\beta$ subunits, myosin, and phosphofructokinase (Fig. 4), and a consensus sequence has been determined (53). The two domains are often separated by 60 to 100 aa, and some proteins (e.g., myosin and phosphofructokinase) contain only one of the two regions. In Vps33p, the two regions are located at residues 480 to 498 and 661 to 679 (Fig. 3).

Disruption of VPS33. Disruption of the VPS33 locus was accomplished by using the one-step gene disruption technique (44) with two different constructions. In the first, the 700-bp EcoRI fragment shown in Fig. 2C was replaced with the HIS3 gene. This disrupted VPS33 construction was digested with $S a l I$ and $X b a I$ and used to transform the parental his3- $\Delta 200$ diploid SEY6210/SEY6211. Two different resulting $\mathrm{His}^{+}$transformants were subjected to tetrad analysis. In each of the 10 asci examined, all spores were viable but a segregation pattern of 2 temperature-sensitive $\mathrm{His}^{+}: 2$ temperature-resistant $\mathrm{His}^{-}$spores was observed. Microscopic examination of the temperature-sensitive segregants streaked on YPD revealed that the cells doubled at most two times at $37^{\circ} \mathrm{C}$. A second construction replaced the entire 2.1-kb HindIII-SmaI fragment (indicated in Fig. 2C) with the HIS3 gene. This construction deleted all but the carboxyterminal $250 \mathrm{bp}$ of the putative VPS33 ORF. Transformation of the haploid strain SEY6210 with the linear SalI-XbaI fragment carrying this construction yielded temperaturesensitive $\mathrm{His}^{+}$transformants. The temperature-sensitive phenotype of one such transformant, LBY317, is shown in Fig. 1. In liquid media, this strain doubles 1.5 times at $37^{\circ} \mathrm{C}$ and exhibits a terminal arrest phenotype in which, after $24 \mathrm{~h}$ at $37^{\circ} \mathrm{C}$, approximately $50 \%$ of the cells contain a medium or large bud and an additional $20 \%$ contain two or more buds. Southern analysis of the chromosomal DNA from these disrupted strains confirmed the removal of the VPS33 sequences and the integration of the HIS3 gene at the VPS33 locus as expected (data not shown). From these results, we conclude that VPS33 is not essential at low temperatures but is required for growth at $37^{\circ} \mathrm{C}$.

As expected, disruption of the VPS33 gene also led to the other phenotypic defects associated with the original mutant alleles. Strains harboring a disrupted VPS33 gene exhibited extreme defects in vacuole morphology and in vacuole protein localization and processing at the permissive temperature (Fig. 5). The vps33 null mutant strain LBY317 was radioactively labeled at $25^{\circ} \mathrm{C}$ for $20 \mathrm{~min}$ and chased for 30 min before immunoprecipitation with antiserum specific for the vacuolar protease CPY. CPY was present almost exclusively in the precursor form in these cells (Fig. 5, lane 2), whereas in wt cells labeled under identical conditions, $100 \%$ of the CPY was present in the mature vacuolar form (lane 1). Previous characterization of vps33 mutants has demonstrated that most $(>70 \%)$ of the precursor CPY is secreted from the cell (40). The $\mathrm{Vps}^{-}$defect exhibited by the null 


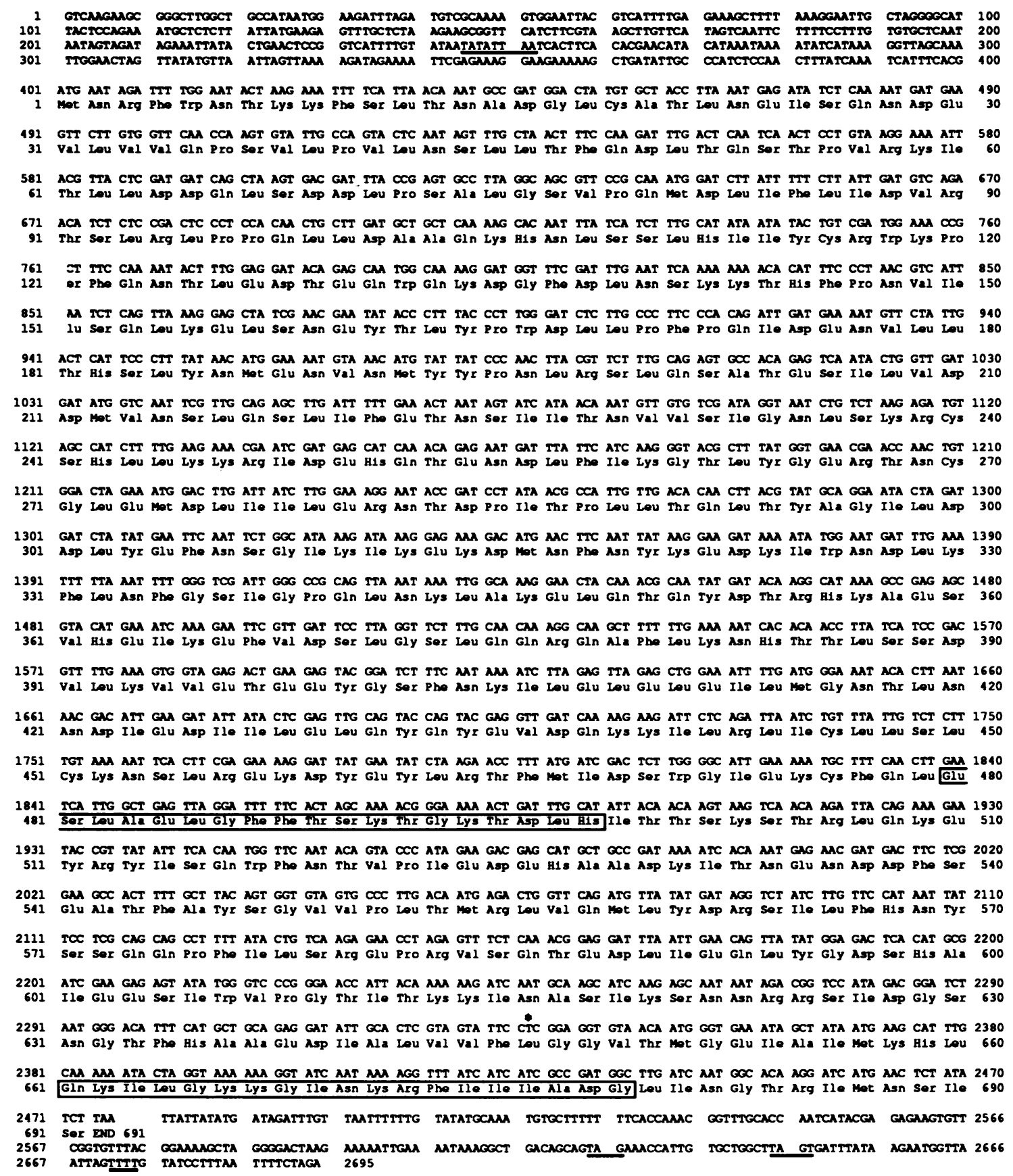

FIG. 3. Sequence of VPS33. The nucleotide sequence and the deduced amino acid sequence of the ORF are shown. The putative transcription initiation and termination sequences are underlined. The regions which share sequence similarity with ATP-binding proteins are boxed. The $\mathrm{T}$ marked with an asterisk is replaced with a $\mathrm{C}$ in vps33-4(Ts).

mutant was completely complemented when the wt VPS33 gene was present on a single-copy vector (lane 3 ).

Identification of Vps33p. To identify Vps33p, we overproduced the VPS33 gene product as two different TrpE-Vps33 hybrid proteins in $E$. coli and raised antisera against the fusion proteins. Two coding fragments of the VPS33 gene, from HindIII-SmaI and from EcoRI-EcoRI, were cloned into the appropriate pATH vectors (6) to generate in-frame fusions to the $\operatorname{trp} E$ gene of $E$. coli. These fragments (Fig. 2C) encode 230 and 164 aa, respectively, of Vps33p. When these constructions were expressed in $E$. coli, hybrid proteins of the expected molecular weights were overproduced upon induction. Both overexpressed proteins were isolated and injected into a single rabbit as described in Materials and Methods. The resulting antisera were used in immunoprecipitation experiments to detect Vps33p. The antibodies recognized a single major species of the predicted molecular weight, $\sim 75,000$, in radioactively labeled wild-type cells (Fig. 6, lane 1). This protein was $\sim 20$-fold more abundant when the VPS33 gene was present on a multicopy plasmid (lane 2) and was not detected in the vps33 null mutant (lane 5 ) or by the preimmune serum (lane 6). Pulse-chase analysis 


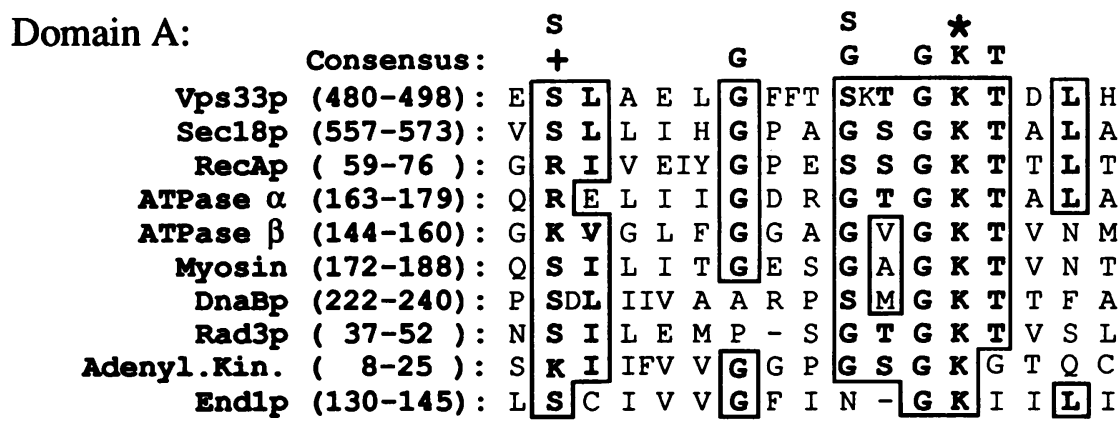

Domain B:

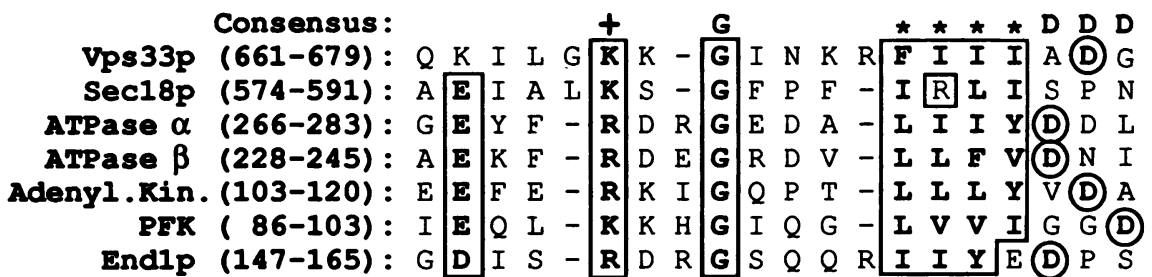

FIG. 4. Comparison of the predicted Vps33p sequence with known and predicted ATP-binding proteins. The deduced amino acid sequence of $\mathrm{Vps} 33 \mathrm{p}$ shares similarity with the proteins listed through the two domains shown. Residues that are highly conserved at a given position are shown in boldface and boxed. and a consensus sequence is indicated above each domain. The significance of the starred lysine in domain $A$ is discussed in the text. In domain B, asterisks denote hydrophobic residues; this region is followed by an aspartic acid in one of the next three positions in each of the proteins listed (53). The sequences shown are taken from Walker et al. (53) (E. coli ATPase $\alpha$ and $\beta$ subunits, adenylate kinase [Adenyl. Kin.], rabbit myosin, phosphofructokinase [PFK], and RecAp), Naumovski and Friedberg (30) (DnaBp and Rad3p), or Dulic and Riezman (8) (End1p). By analogy to the $N$-ethylmaleimide-sensitive factor of mammalian cells, with which it is functionally equivalent (56), the yeast Sec18p (9) is also predicted to bind ATP.

suggests that the turnover rate for Vps33p is relatively slow; after a 30 - or 90-min chase, there was no significant difference in the amount of the protein produced from a multicopy plasmid. Comparison with CPY indicates that the VPS33 gene product is present at very low levels in wt yeast cells. By densitometric quantitation, we estimate that the production of $\mathrm{Vps} 33 \mathrm{p}$ from the multicopy plasmid is comparable to the level of expression of CPY from the chromosomal locus ( 0.05 to $0.1 \%$ of the total cell protein). Cells were also labeled in the presence of tunicamycin, an inhibitor of $\mathrm{N}$-linked glycosylation (10). The size of $\mathrm{Vps} 33 \mathrm{p}$ was unaffected by the drug (Fig. 6, lanes 3 and 4), indicating that none of the seven potential sites for $\mathrm{N}$-linked carbohydrate addition (24) (Asn-X-Ser/Thr) is utilized.

The subcellular localization of Vps33p was examined by cellular fractionation and immunoprecipitation studies.

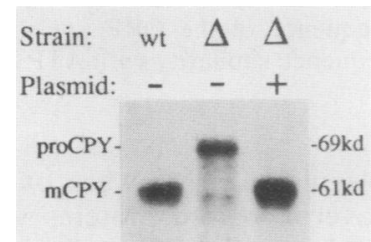

FIG. 5. Processing of CPY in a vps33 null mutant in the presence and absence of the cloned VPS33 gene. Whole cells were labeled with $\operatorname{Tran}^{35} \mathrm{~S}$ label for $20 \mathrm{~min}$ at $25^{\circ} \mathrm{C}$, chased for $30 \mathrm{~min}$ by the addition of $4 \mathrm{mM}$ methionine, and subjected to immunoprecipitation with CPY-specific antisera. The migration positions of precursor (proCPY) and mature (mCPY) forms are indicated. The isogenic strains used were as follows: lane 1, VPS ${ }^{+}$(SEY6210); lane 2, vps33 null mutant (LBY317); and lane 3, vps33 null mutant carrying the cloned VPS33 gene on a single-copy plasmid [LBY317(pLB33-162)].
Wild-type cells carrying VPS33 on a multicopy plasmid were converted to spheroplasts, radioactively labeled, and osmotically lysed under a variety of conditions before being subjected to centrifugation at $100,000 \times g$ for $90 \mathrm{~min}$. These centrifugation conditions were sufficient to pellet $>95 \%$ of the vacuolar membrane protein alkaline phosphatase, whereas the cytosolic marker enzyme glyceraldehyde 3-

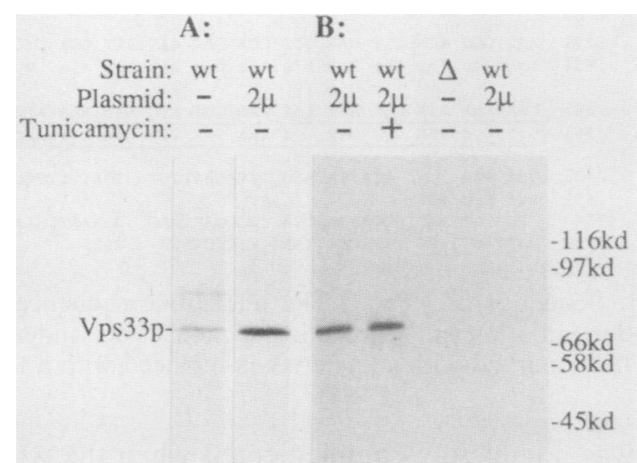

FIG. 6. Identification of the VPS33 gene product. Spheroplasts (A) or whole cells (B) were labeled and chased as described in the legend to Fig. 5. Strains used were parental strain SEY6210 (lane 1), SEY6210 carrying VPS33 on the multicopy plasmid pLB33-221 (lanes 2, 3, 4, and 6), or the vps33 null mutant LBY317 (lane 5). Tunicamycin was added to a $20-\mu \mathrm{g} / \mathrm{ml}$ final concentration as indicated $15 \mathrm{~min}$ before the addition of the radioactive label. Immunoprecipitations were performed by using the preimmune (lane 6) or Vps33p immune (lanes 1 to 5 ) sera. The migration positions for molecular size standards are indicated in kilodaltons ( $\mathrm{kd})$. In panel $\mathrm{A}$, the exposure time for lane 1 was twice as long as for lane 2. 


\begin{tabular}{lllll}
$\mathrm{KCl}(\mathrm{mM}):$ & & & & \multicolumn{2}{c}{500} \\
& $\mathrm{~S}$ & $\mathrm{P}$ & $\mathrm{S}^{\mathrm{P}}$ & \\
$\mathrm{Vps} 33 \mathrm{p} \rightarrow-$ & & & & \\
& & & &
\end{tabular}

FIG. 7. Subcellular fractionation of Vps33p. Strain SEY6210 carrying VPS33 on the multicopy plasmid pLB33-221 was enzymatically converted to spheroplasts. Spheroplasts were labeled at $30^{\circ} \mathrm{C}$ for $20 \mathrm{~min}$ and chased for $30 \mathrm{~min}$ by the addition of $4 \mathrm{mM}$ methionine. Labeled spheroplasts were pelleted and osmotically lysed as described in Materials and Methods in lysis buffer containing the indicated concentration of $\mathrm{KCl}$. Two representative conditions are shown; other concentrations of $\mathrm{KCl}(100 \mathrm{mM}, 250 \mathrm{mM}$, and $1 \mathrm{M})$ gave identical results. Unlysed cells were removed by centrifugation at $500 \times g$, and the resulting lysate was centrifuged at $100,000 \times g$ for $90 \mathrm{~min}$ at $4^{\circ} \mathrm{C}$. The supernatant (S) and pellet (P) fractions were processed as described in Materials and Methods and immunoprecipitated with antiserum to Vps33p.

phosphate dehydrogenase was found exclusively in the supernatant fraction (data not shown). The results of two representative experiments are shown in Fig. 7. Vps33p was found primarily in the supernatant fraction; this solubility was not affected by varying the salt concentration of the lysis buffer from 0 to $1 \mathrm{M} \mathrm{KCl}$ or by varying the $\mathrm{pH}$ of the lysis buffer (7.5 to 6.5 or 8.0) (44) (data not shown). These results suggest that the VPS33 gene product resides in the cytoplasm and is not tightly associated with any membrane fraction. Vps33p expressed from the chromosomal VPS33 locus, although considerably more difficult to detect, also behaved as a soluble cytosolic protein in cell fractionation studies (data not shown). These observations do not, however, exclude the possibility that Vps33p associates weakly or transiently with some subcellular membrane or complex. By immunofluorescence studies, we have detected a weak background fluorescence that may be due to cytoplasmic staining (data not shown).

vps33 mutant strain SEY33-4 exhibits a bud vacuole defect. Wild-type vacuoles can be visualized in live cells by using various dyes, including CDCFDA (38) and FITC (37), that accumulate in this organelle. As previously mentioned, most of the class $\mathrm{C}$ vps mutants exhibit extreme defects in vacuole morphology in that they contain no compartments that resemble wt vacuoles. Instead, they accumulate many small vesicles and other membranous structures (2). When these class C vps mutants are stained with CDCFDA or FITC, only small speckles of fluorescence are detected. Two vps33 mutant strains, SEY33-4 and SEY33-5, however, do not exhibit these gross abnormalities in their vacuole morphologies. Instead, they contain vacuoles that stain like those in wt cells. Unlike the other, more extreme vps33 mutants, these strains also are not sensitive to osmotic stress. Furthermore, SEY33-4 and SEY33-5 are only moderately defective in vacuole protein localization, missorting $\sim 40 \%$ of the soluble vacuolar protease CPY. One of these strains, however, is temperature sensitive for growth. This strain, SEY33-4, was found to contain morphologically wt vacuoles, as visualized by using either CDCFDA or FITC, in both the mother cell and the bud at $25^{\circ} \mathrm{C}$, the permissive temperature (Fig. 8A and B). However, when the strain was shifted to the nonpermissive temperature $\left(37^{\circ} \mathrm{C}\right)$ for $2 \mathrm{~h}$, budding cells were observed in which the bud did not appear to have any stain (Fig. 8C and D). Incubation for longer times at $37^{\circ} \mathrm{C}$ resulted in fewer buds with detectable vacuole staining (Fig. $8 \mathrm{E}$ to J). By $6 \mathrm{~h}$ after the shift to $37^{\circ} \mathrm{C}$, only a small fraction of the buds had vacuole fluorescence, and some unbudded cells exhibited a typical class $C$ phenotype in that little or no vacuole fluorescence was visible (Fig. 8J). The wt parental strain SEY6210 is shown for comparison in Fig. 8K and L. Under identical staining conditions, bud vacuole fluorescence was clearly visible in these cells at $25^{\circ} \mathrm{C}$ (Fig. 8K) or after $6 \mathrm{~h}$ at $37^{\circ} \mathrm{C}$ (Fig. 8L). The extent of the bud vacuole staining defect in SEY33-4 was quantitated (Fig. 8). When SEY33-4 was grown at $25^{\circ} \mathrm{C}, 80 \%$ of the buds examined contained vacuole fluorescence. After $6 \mathrm{~h}$ at $37^{\circ} \mathrm{C}$, only $14 \%$ of the buds exhibited vacuole staining. The vacuole protein processing phenotype of SEY33-4 was also exacerbated by exposure to $37^{\circ} \mathrm{C}$. After $6 \mathrm{~h}$ at $37^{\circ} \mathrm{C}, \sim 70 \%$ of the CPY accumulated in the precursor form, as compared with $40 \%$ at $25^{\circ} \mathrm{C}$ (Fig. 9B; compare lanes 2 and 6). The temperature-sensitive mutation and the bud vacuole defect in SEY33-4 are genetically linked to the vacuole protein processing defect $(2,40)$, and each of the defects is completely complemented by the cloned VPS33 gene.

The vps33-4(Ts) mutation results in a Leu-646 $\rightarrow$ Pro change. The temperature-sensitive mutation in SEY33-4 was mapped by using a strategy of recombinational rescue. Initially, SEY33-4 was transformed with the noncomplementing plasmid pLB33-23 or pLB33-24 (Fig. 2B); transformants streaked on YPD plates were incubated at $37^{\circ} \mathrm{C}$, and the presence or absence of temperature-resistant colonies was scored. Many temperature-resistant recombinants were obtained from SEY33-4 harboring pLB33-23, indicating that the temperature-sensitive mutation likely lies $3^{\prime}$ of the ClaI site within the ORF. Various fragments containing this region of the VPS33 gene were subcloned into the multicopy vector pSEY18, and SEY33-4 transformants carrying these plasmids were again scored for the frequency at which temperature-resistant revertants arose. The results of this analysis (data not shown) suggested that the temperaturesensitive mutation mapped to the 250 -bp region between the SmaI site and the end of the ORF (Fig. 2C). The chromosomal mutation was recovered by transforming SEY33-4 with a replicating plasmid carrying VPS33 containing a double-stranded gap between the $S m a I$ and $X b a I$ sites (33). Sequencing of the SmaI-XbaI fragment from the rescued plasmid revealed that a single base pair change within the ORF, resulting in a leucine-to-proline change at residue 646 , was responsible for the temperature sensitivity. The predicted amino acid sequences of the wt VPS33 gene product and the mutant Vps33p carrying the Leu- $646 \rightarrow$ Pro alteration were subjected to Chou-Fasman analysis (5). The presence of proline at position 646 is predicted to cause a structural change in the VPS33 gene product, inserting a turn in a region that is expected to form a random coil in the wt protein.

The nature of the temperature sensitivity was examined by retransforming various wt and vps 33 strains with the vps 33 gene carrying the rescued temperature-sensitive mutation on single and multicopy vectors. Transformation of SEY33-4 with a second copy of the temperature sensitive mutant allele resulted in a strain which grew slightly better at $37^{\circ} \mathrm{C}$ than did the original mutant. A null mutant carrying the vps33-4 mutant allele on a single-copy vector had a growth rate comparable to that of the original mutant allele. Both mutants exhibited wt growth at $37^{\circ} \mathrm{C}$ when the temperaturesensitive allele was present on a multicopy vector. Transformation of the wt strain SEY6210 with either the single-copy or the multicopy construction did not affect its ability to 

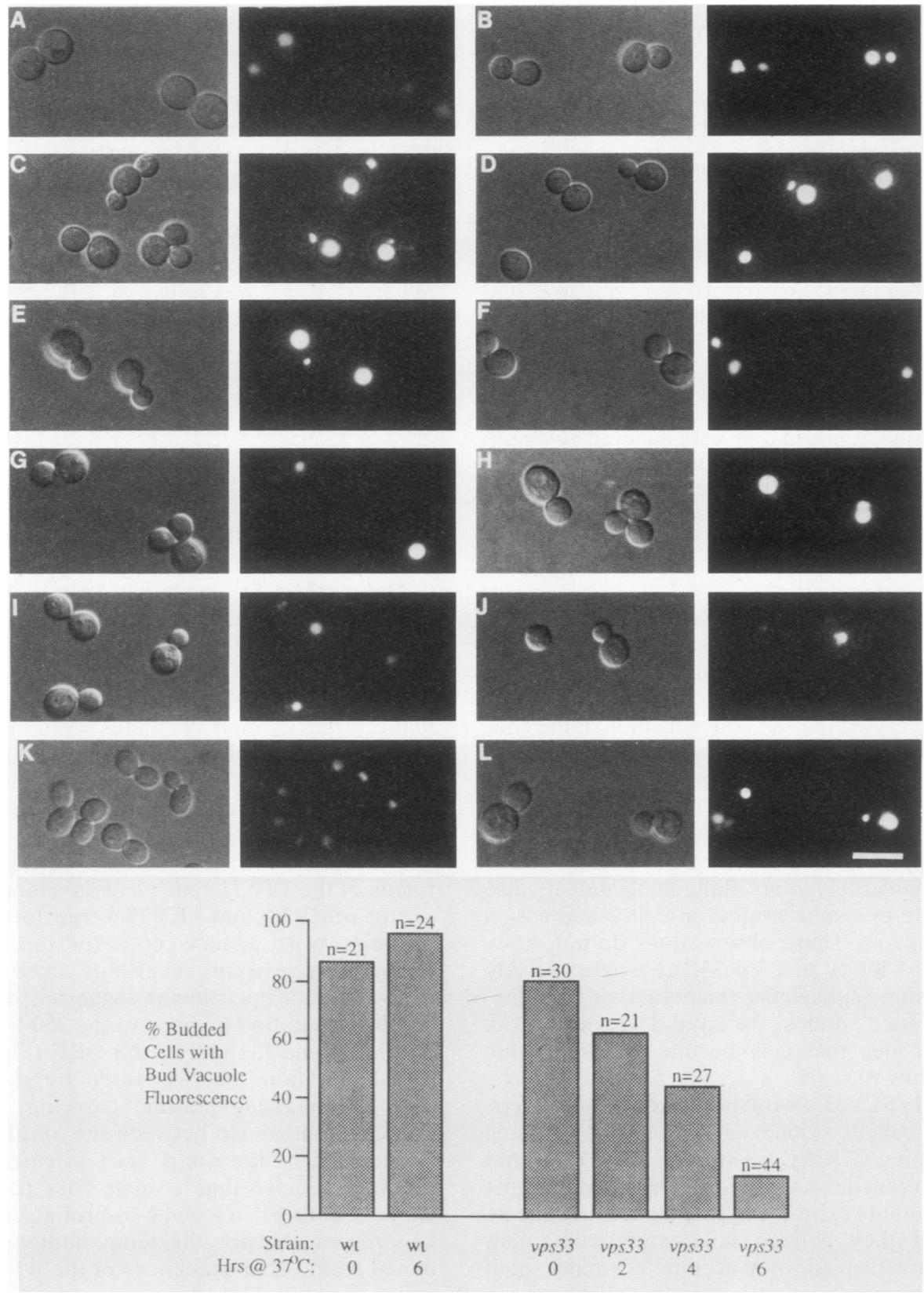

FIG. 8. Mother and bud vacuole staining in SEY33-4. SEY33-4 was grown in YPD at $25^{\circ} \mathrm{C}$ (A and B) and shifted to $37^{\circ} \mathrm{C}$ for $2 \mathrm{~h}$ (C and D), $4 \mathrm{~h}(\mathrm{E}$ and $\mathrm{F})$, or $6 \mathrm{~h}(\mathrm{G}$ to $\mathrm{J})$ before harvesting. Also shown for comparison is the parental strain SEY 6210 grown at $25^{\circ} \mathrm{C}(\mathrm{K})$ and shifted to $37^{\circ} \mathrm{C}$ for $6 \mathrm{~h}(\mathrm{~L})$. Cells were stained with FITC as described in Materials and Methods and observed by using Nomarski (left) or fluorescence (right) optics. The number of buds exhibiting vacuole fluorescence was quantitated and expressed as a percentage of the total number of large budded cells (n). Cells were grown at $25^{\circ} \mathrm{C}$, incubated at $37^{\circ} \mathrm{C}$ for the indicated lengths of time, and stained with FITC as described above. Bar, $10 \mu \mathrm{m}$.

grow at $37^{\circ} \mathrm{C}$ (Fig. 9A). Thus, the mutant allele vps33-4(Ts) is recessive to the wt allele even when overproduced. Furthermore, strains carrying the vps33-4 mutant allele appeared to exhibit a dosage-dependent growth phenotype; overexpression of the mutant allele resulted in complementation of the temperature-sensitive defect of the null mutant or SEY33-4. However, although the strains carrying multiple copies of vps33-4 were temperature resistant, they still exhibited a partial $\mathrm{Vps}^{-}$phenotype. Immunoprecipitation experiments indicated that $15 \%$ of the CPY accumulated in the precursor form in SEY33-4 carrying the temperature-sensitive allele on a multicopy plasmid (Fig. 9B). Together, our observations suggest that the vps $33-4$ mutant allele encodes a partially functional protein and that multiple copies of this protein can compensate for its diminished activity. The partial function of this Vps33-4p is unlikely to be a result of inactivation of the $\mathbf{4 5}$ aa following the changed residue, since a 3 ' truncation of the VPS33 gene, lacking the coding sequence for the carboxy-terminal 56 aa, is unable to complement a vps33 null mutation (data not shown). 

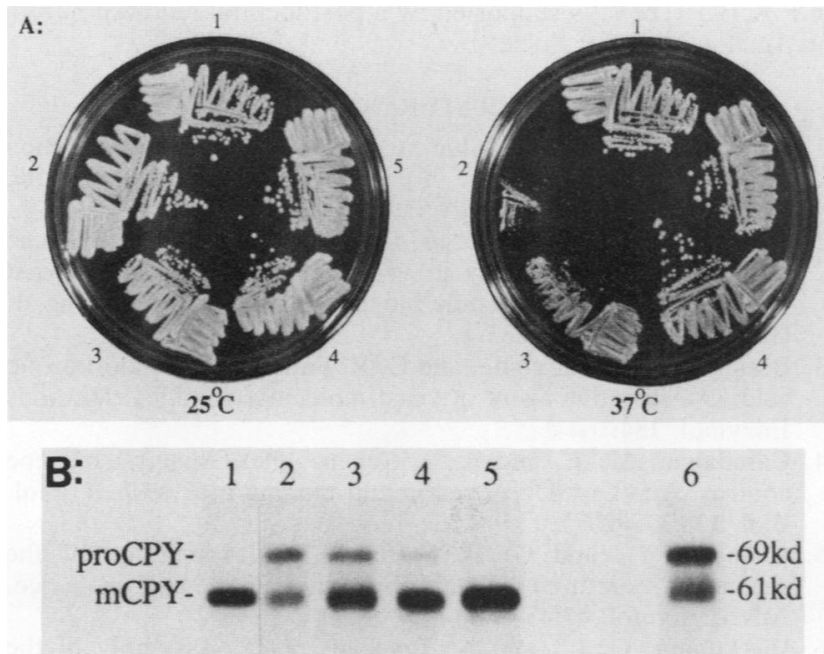

FIG. 9. Rescue of the SEY33-4 phenotypic defects by overexpression of the mutant allele. (A) The indicated strains were streaked on YPD solid medium and incubated at 25 or $37^{\circ} \mathrm{C} .1$, Parental strain SEY6210; 2, SEY33-4; 3, SEY33-4 carrying the plasmid pLB33-161 [vps33-4(Ts) allele on a single-copy vector]; 4, SEY33-4 carrying the plasmid pLB33-271 [vps33-4(Ts) allele on a multicopy vector]; 5, SEY6210 carrying pLB33-271. (B) Whole cells were labeled and chased at $25^{\circ} \mathrm{C}$ (lanes 1 to 5) or $37^{\circ} \mathrm{C}$ (lane 6) and subjected to immunoprecipitation with CPY-specific antisera as described in the legend to Fig. 5. Lanes 1 to 5 contain the strains listed above; for lane 6, SEY33-4 was grown at $25^{\circ} \mathrm{C}$ and shifted to $37^{\circ} \mathrm{C}$ for $5 \mathrm{~h}$ before radioactive labeling. Wild-type cells grown and labeled under these conditions contain CPY exclusively in the mature form (data not shown). The migration positions of precursor (proCPY) and mature (mCPY) forms are shown.

\section{DISCUSSION}

VPS33, a gene required for vacuole protein sorting and normal vacuole formation, has been cloned and sequenced. Disruption of VPS33 leads to a temperature-sensitive growth phenotype (Fig. 1), indicating that the gene is essential for growth only at elevated temperatures. At the permissive temperature, the null mutants are extremely defective in vacuolar protein processing and sorting (Fig. 5) and lack any structure resembling a wt vacuole. These phenotypes are comparable to those exhibited by most of the original vps33 mutants, implying that many of the originally isolated alleles may be null (complete loss of function) mutations. The temperature sensitivity of the null mutants likely reflects a requirement at $37^{\circ} \mathrm{C}$ for one or more vacuolar functions that cannot be provided by whatever vacuole remnants remain in these mutant cells.

The phenotypes exhibited by vps33 mutants resemble those of the recently described mutant slpl (17). This mutant was originally selected for its sensitivity to lysine. The strain contains smaller than normal vacuolar pools of lysine, arginine, and histidine and is characterized by pleiotropic defects, including lowered activities of soluble vacuolar enzymes such as CPY and proteinase $A$ and an aberrant morphology in which many small vesicles but no large vacuoles are observed. Complementation analysis revealed that the slpl and vps33 mutants define a single complementation group (L. Banta, S. Emr, Y. Wada, and Y. Anraku, unpublished observations). Comparison of the restriction maps and sequences of our VPS33 clone and the recently cloned $S L P 1$ gene (52) has demonstrated that the two genes are identical.
Antibodies raised against a TrpE-Vps33 fusion protein recognize a relatively rare protein in yeast cells $(<0.01 \%$ of cell protein) of $\sim 75 \mathrm{kDa}$ (Fig. 6). In cell fractionation experiments, Vps33p behaves as a soluble cytoplasmic protein under a variety of lysis conditions (Fig. 7). The hydrophilic nature of the predicted amino acid sequence and the apparent lack of $\mathrm{N}$-linked glycosylation (Fig. 6) are consistent with a cytoplasmic location for $\mathrm{Vps} 33 \mathrm{p}$.

The predicted amino acid sequence of $\mathrm{Vps} 33 \mathrm{p}$ possesses two regions of similarity with a number of ATPases and ATP-binding proteins (Fig. 4). Several studies suggest that these domains are directly involved in nucleotide binding or enzyme function. The conserved lysine residue in adenylate kinase, marked with an asterisk in Fig. 4, Domain A, has been shown by affinity labeling and other experiments to interact with $\operatorname{ATP}(7,12,51)$, and mutagenesis of the corresponding lysine in the $E$. coli ATPase $\alpha$ or $\beta$ subunit impaired apparent ATP-binding and catalytic activity (34, 39). A truncated form of VPS33, in which the coding sequence for aa 636 to 691 (including the second region of ATP-binding protein homology) has been deleted, is unable to complement the temperature-sensitive or class $\mathrm{C}$ defects associated with a vps33 null mutation. This observation is consistent with the idea that the region of sequence similarity between Vps33p and the family of ATP-binding proteins is functionally significant. A second class $\mathrm{C} v p s$ mutant, $v p s 11$, falls into the same complementation group as the mutant endl $(8,40)$. The ENDl gene has been cloned and sequenced (8). This gene also shares sequence similarity with VPS33 and the family of ATP-binding protein genes throughout the two conserved domains. This observation raises the interesting possibility that ATP binding (and perhaps ATP hydrolysis) plays a role in vacuolar protein sorting and vacuole biogenesis. Further experiments, such as ATP-binding studies and affinity labeling, will be necessary to determine whether Vps33p does indeed bind ATP.

One vps 33 mutant strain, SEY33-4, exhibits a particularly interesting temperature-conditional defect in vacuolar protein sorting and vacuole inheritance. At the permissive temperature, this temperature-sensitive strain mislocalizes $40 \%$ of the CPY but contains vacuoles that are apparently normal by a number of criteria. These vacuoles exhibit wt staining with a variety of dyes, including quinacrine, a compound that accumulates in vacuoles in a $\mathrm{pH}$-dependent manner (2, 54; L. Banta, unpublished observations). Unlike the more defective class C strains, SEY33-4 does not mislocalize the vacuolar membrane enzyme $\alpha$-mannosidase to the cell surface and is able to process $60 \%$ of the CPY to the mature form, indicating that the vacuoles in these cells are able to function as acceptor compartments for at least some vacuolar proteins. Upon incubation of SEY33-4 at $37^{\circ} \mathrm{C}$, budding cells appear to lack vacuole staining selectively in the bud (Fig. 8) and the vacuolar protein processing defect is exacerbated (Fig. 9). The temperature-sensitive defect in this strain is due to a single base pair substitution which results in a leucine-to-proline change at position 646 in the VPS33 gene product. This mutation is predicted to cause a structural change in the carboxy terminus of the protein.

The bud vacuole defect and increase in protein missorting observed in SEY33-4 at the nonpermissive temperature suggest a number of possible roles for the wt $\mathrm{Vps} 33 \mathrm{p}$ in vacuole biogenesis. For example, Vps33p may be required for (i) vacuole segregation to the bud during cell division (55), (ii) maintenance of normal vacuolar structure, or (iii) sorting and delivery of vacuolar proteins between the Golgi and the vacuole. For the following reasons, we favor a model 
in which Vps33p acts primarily in Golgi-to-vacuolar protein transport. The observation that $\mathrm{Vps} 33 \mathrm{p}$ fractionates as a cytosolic protein suggests that this protein is not a structural component of the vacuole itself. In addition, the existence of SEY33-4 and a second vps33 strain, SEY33-5, that mislocalize CPY yet contain apparently normal vacuoles at $25^{\circ} \mathrm{C}$ is inconsistent with a structural function for $\mathrm{Vps} 33 \mathrm{p}$ in maintaining vacuole integrity. A primary role for $V p s 33 p$ in vacuole inheritance also seems unlikely, given that SEY33-4 and SEY33-5 exhibit apparently normal vacuole segregation patterns during cell division at the permissive temperature. These observations suggest that the primary defect in these mutants lies in Golgi-to-vacuole trafficking. If Vps33p were directly involved in vacuole inheritance or vacuolar structure, mutants that clearly affect vacuole protein localization would also be expected to exhibit morphological abnormalities in the vacuole.

The simplest explanation for the extreme abnormalities in vacuole morphology exhibited by most of the vps 33 mutants is that as a consequence of a primary defect in Golgi-tovacuole protein transport, proteins necessary for vacuolar inheritance or structural stability are mislocalized. In strong $v p s 33$ mutants, which exhibit partial missorting of a vacuolar membrane component as well as almost completely aberrant targeting of soluble hydrolases, vacuole assembly is severely impaired. The less defective mutant SEY33-4 appears to contain a partially functional $\mathrm{Vps} 33 \mathrm{p}$. The residual activity is sufficient to permit some Golgi-to-vacuole protein transport and thus the formation of nearly normal vacuoles. The lack of a vacuole in the bud at $37^{\circ} \mathrm{C}$ may reflect a more complete loss of function if, for example, the mutant protein is less stable at high temperatures. We cannot exclude, however, the possibility that the VPS33 gene product is bifunctional, with roles in both vacuole protein targeting and vacuole maintenance or segregation to emerging buds. In this scenario, the protein encoded by the vps33-4 allele might be defective in only the former function at $25^{\circ} \mathrm{C}$ but both functions at $37^{\circ} \mathrm{C}$.

A possible role for $\mathrm{Vps} 33 \mathrm{p}$ in Golgi-to-vacuole sorting is suggested by a recent observation that the protein is phosphorylated in vivo (P. Herman, J. Stack, and S. Emr, unpublished observations). Perhaps Vps33p undergoes a cycle of phosphorylation-dephosphorylation, which in turn regulates its activity in promoting Golgi-to-vacuole protein transport. Since this transport is assumed to be vesicle mediated, the VPS33 gene product could act at the level of vesicle formation, transport, or fusion with the target organelle. The accumulation of many small vesicles in vps33 mutant cells (2) suggests that the defect in these strains may occur after vesicle formation. Using the probes developed in this study in conjunction with an in vitro assay for protein transport from the Golgi to the vacuole (T. A. Vida, T. R. Graham, and S. D. Emr, submitted for publication), we hope to determine the step(s) at which Vps33p acts as well as the significance of the observed phosphorylation.

\section{ACKNOWLEDGMENTS}

We thank Raffi Aroian for the YCp50 library DNA, Dan Klionsky for many helpful discussions, and Elliot Altman, Editte Gharakhanian, and Bruce Horazdovsky for critically reading the manuscript. We also thank Yoh Wada and Yasuhiro Anraku for communicating results prior to publication.

This work was supported by Public Health Service grant GM32703 from the National Institutes of Health (to S.D.E.). Partial support was also provided by General Electric Co. (to L.M.B.) and the Natural Sciences and Engineering Research Council of Canada (to P.K.H.) T.A.V. is supported by a postdoctural fellowship from the American Cancer Society.

\section{LITERATURE CITED}

1. Bankaitis, V. A., L. M. Johnson, and S. D. Emr. 1986. Isolation of yeast mutants defective in protein targeting to the vacuole. Proc. Natl. Acad. Sci. USA 83:9075-9079.

2. Banta, L. M., J. S. Robinson, D. J. Klionsky, and S. D. Emr. 1988. Organelle assembly in yeast: characterization of yeast mutants defective in vacuole biogenesis and protein sorting. J. Cell Biol. 107:1369-1383.

3. Boeke, J. D., F. Lacroute, and G. R. Fink. 1987. 5-Fluoroorotic acid as a selective agent in yeast molecular genetics. Methods Enzymol. 154:164-175.

4. Casadaban, M. J., and S. N. Cohen. 1980. Analysis of gene control signals by DNA fusion and cloning in E. coli. J. Mol. Biol. 138:179-207.

5. Chou, P. Y., and G. D. Fasman. 1978. Prediction of the secondary structure of proteins from their amino acid sequence. Adv. Enzymol. 47:45-148.

6. Dieckmann, C. L., and A. Tzagoloff. 1985. Assembly of the mitochondrial membrane system. CBP6, a yeast nuclear gene necessary for synthesis of cytochrome b. J. Biol. Chem. 260: 1513-1520.

7. Dreusicke, D., and G. E. Schulz. 1986. The glycine-rich loop of adenylate kinase forms a giant anion hole. FEBS Lett. 208:301304.

8. Dulic, V., and H. Riezman. 1989. Characterization of the ENDI gene required for vacuole biogenesis and gluconeogenic growth of budding yeast. EMBO J. 8:1349-1359.

9. Eakle, K. A., M. Bernstein, and S. D. Emr. 1988. Characterization of a component of the yeast secretion machinery: identification of the SEC18 gene product. Mol. Cell. Biol. 8:4098-4109.

10. Elbein, A. D. 1987 . Inhibitors of the biosynthesis and processing of N-linked oligosaccharide chains. Annu. Rev. Biochem. 56: 497-534.

11. Emr, S. D., A. Vassarotti, J. Garrett, B. L. Geller, M. Takeda, and M. G. Douglas. 1986. The amino terminus of the yeast $F_{1}$-ATPase $\beta$-subunit precursor functions as a mitochondrial import signal. J. Cell Biol. 102:523-533.

12. Fry, D. C., S. A. Kuby, and A. S. Mildvan. 1986. ATP-binding site of adenylate kinase: mechanistic implications of its homology with ras-encoded $\mathrm{p} 21, \mathrm{~F}_{1}$-ATPase, and other nucleotidebinding proteins. Proc. Natl. Acad. Sci. USA 83:907-911.

13. Hanahan, D. 1983. Studies on the transformation of Escherichia coli with plasmids. J. Mol. Biol. 166:557-580.

14. Hasilik, A., and W. Tanner. 1978. Biosynthesis of the vacuolar yeast glycoprotein carboxypeptidase $\mathrm{Y}$. Conversion of precursor into the enzyme. Eur. J. Biochem. 85:599-608.

15. Hemmings, B. A., G. S. Zubenko, A. Hasilik, and E. W. Jones. 1981. Mutant defective in processing of an enzyme located in the lysosome-like vacuole of Saccharomyces cerevisiae. Proc. Natl. Acad. Sci. USA 78:435-439.

16. Ito, H., Y. Fukada, K. Murata, and A. Kimura. 1983. Transformation of intact yeast cells treated with alkali cations. J. Bacteriol. 153:163-168.

17. Kitamoto, K., K. Yoshizawa, Y. Ohsumi, and Y. Anraku. 1988. Mutants of Saccharomyces cerevisiae with defective vacuolar function. J. Bacteriol. 170:2687-2691.

18. Kleid, D. G., D. Yansura, B. Small, D. Dowbenko, D. M. Moore, M. G. Grubman, P. D. McKercher, D. O. Morgan, B. H. Robertson, and H. L. Bachrach. 1981. Cloned viral protein vaccine for foot-and-mouth disease: responses in cattle and swine. Science 214:1125-1129.

19. Klionsky, D. J., L. M. Banta, and S. D. Emr. 1988. Intracellular sorting and processing of a yeast vacuolar hydrolase: proteinase A propeptide contains vacuolar targeting information. Mol. Cell. Biol. 8:2105-2116.

20. Koller, K. J., and M. J. Brownstein. 1987. Use of a cDNA to identify a supposed precursor protein containing valosin. $\mathrm{Na}$ ture (London) 325:542-545.

21. Kyte, J., and R. F. Doolittle. 1982. A simple method for displaying the hydropathic character of a protein. J. Mol. Biol. 
157:105-132.

22. Laemmli, U. K. 1970. Cleavage of structural proteins during the assembly of the head of bacteriophage T4. Nature (London) 277:680-685.

23. Maniatis, T., E. F. Fritsch, and J. Sambrook. 1982. Molecular cloning: a laboratory manual. Cold Spring Harbor Laboratory, Cold Spring Harbor, N.Y.

24. Marshall, R. D. 1972. Glycoproteins. Annu. Rev. Biochem. 41:673-702.

25. McNeil, J. B., and J. D. Friesen. 1981. Expression of the herpes simplex virus thymidine kinase gene in Saccharomyces cerevisiae. Mol. Gen. Genet. 184:386-393.

26. Mechler, B., M. Müller, H. Müller, M. Meussdoerffer, and D. H. Wolf. 1982. In vivo biosynthesis of the vacuolar proteinases A and B in the yeast Saccharomyces cerevisiae. J. Biol. Chem. 257:11203-11206.

27. Messing, J. 1979. Recombinant DNA technical bulletin. National Institutes of Health publication no. 79-99. 2:43-48.

28. Miller, J. 1972. Experiments in molecular genetics. Cold Spring Harbor Laboratory, Cold Spring Harbor, N.Y.

29. Nakano, A., D. Brada, and R. Schekman. 1988. A membrane glycoprotein, Sec12p, required for protein transport from the endoplasmic reticulum to the Golgi apparatus in yeast. J. Cell Biol. 107:851-863.

30. Naumovski, L., and E. C. Friedberg. 1986. Analysis of the essential and excision repair functions of the RAD3 gene of Saccharomyces cerevisiae by mutagenesis. Mol. Cell. Biol. 6:1218-1227.

31. Oliver, S. G., and J. R. Warmington. 1989. Transcription, p. 117-160. In A. H. Rose, and J. S. Harrison (ed.), The yeasts, vol. 3, 2nd ed. Academic Press, Inc. (London), Ltd., London.

32. Orr-Weaver, T. L., J. W. Szostak, and R. J. Rothstein. 1981. Yeast transformation: a model system for the study of recombination. Proc. Natl. Acad. Sci. USA 78:6354-6358.

33. Orr-Weaver, T. L., J. W. Szostak, and R. J. Rothstein. 1983. Genetic applications of yeast transformation with linear and gapped plasmids. Methods Enzymol. 101:228-245.

34. Parsonage, D., S. Wilke-Mounts, and A. E. Senior. 1987. Directed mutagenesis of the $\beta$-subunit of $F_{1}$-ATPase from Escherichia coli. J. Biol. Chem. 262:8022-8026.

35. Patterson, T. E., and R. O. Poyton. 1986. COX8, the structural gene for yeast cytochrome $\mathrm{c}$ oxidase subunit VIII. DNA sequence and gene disruption indicate that subunit VIII is required for maximal levels of cellular respiration and is derived from a precursor which is extended at both its $\mathrm{NH}_{2}$ and $\mathrm{COOH}$ termini. J. Biol. Chem. 261:17192-17197.

36. Pearson, W. R., and D. J. Lipman. 1988. Improved tools for biological sequence analysis. Proc. Natl. Acad. Sci. USA 85: 2444-2448.

37. Preston, R. A., R. F. Murphy, and E. W. Jones. 1987. Apparent endocytosis of fluorescein isothiocyanate-conjugated dextran by Saccharomyces cerevisiae reflects uptake of low molecular weight impurities, not dextran. J. Cell Biol. 105:1981-1987.

38. Pringle, J. R., R. A. Preston, A. E. M. Adams, T. Stearns, D. G. Drubin, B. F. Haarer, and E. W. Jones. 1989. Fluorescence microscopy methods for yeast. Methods Cell Biol. 31:357-435.

39. Rao, R., J. Pagan, and A. E. Senior. 1988. Directed mutagenesis of the strongly conserved lysine 175 in the proposed nucleotidebinding domain of $\alpha$-subunit from Escherichia coli $\mathrm{F}_{1}$-ATPase. J. Biol. Chem. 263:15957-15963.
40. Robinson, J. S., D. J. Klionsky, L. M. Banta, and S. D. Emr. 1988. Protein sorting in Saccharomyces cerevisiae: isolation of mutants defective in the delivery and processing of multiple vacuolar hydrolases. Mol. Cell. Biol. 8:4936-4948.

41. Rose, M. D., P. Novick, J. H. Thomas, D. Botstein, and G. R. Fink. 1987. A Saccharomyces cerevisiae genomic plasmid bank based on a centromere-containing shuttle vector. Gene. 60:237243.

42. Rothman, J. H., I. Howald, and T. H. Stevens. 1989. Characterization of genes required for protein sorting and vacuolar function in the yeast Saccharomyces cerevisiae. EMBO J. 8:2057-2065.

43. Rothman, J. H., and T. H. Stevens. 1986. Protein sorting in yeasts: mutants defective in vacuole biogenesis mislocalize vacuolar proteins into the late secretory pathway. Cell 47:10411051.

44. Rothstein, R. J. 1983. One step gene disruption in yeast. Methods Enzymol. 101:202-211.

45. Salminen, A., and P. J. Novick. 1989. The Sec15 protein responds to the function of the GTP binding protein, Sec4, to control vesicular traffic in yeast. J. Cell Biol. 109:1023-1036.

46. Sanger, F., S. Nicklen, and A. R. Coulson. 1977. DNA sequencing with chain-terminating inhibitors. Proc. Natl. Acad. Sci. USA 74:5463-5467.

47. Sherman, F., G. R. Fink, and C. W. Lawrence. 1979. Methods in yeast genetics: a laboratory manual. Cold Spring Harbor Laboratory, Cold Spring Harbor, N.Y.

48. Spindler, K. R., D. S. E. Rosser, and A. J. Berk. 1984. Analysis of adenovirus transforming proteins from early regions $1 \mathrm{~A}$ and $1 B$ with antisera to inducible fusion antigens produced in Escherichia coli. J. Virol. 49:132-141.

49. Stevens, T., B. Esmon, and R. Schekman. 1982. Early stages in the yeast secretory pathway are required for transport of carboxypeptidase $Y$ to the vacuole. Cell 30:439-448.

50. Stratagene. 1988. Bluescript exo/mung DNA sequencing system instruction manual. Stratagene, La Jolla, Calif.

51. Tagaya, M., T. Yagami, and T. Fukui. 1987. Affinity labeling of adenylate kinase with adenosine diphosphopyridoxal. Presence of Lys21 in the ATP-binding site. J. Biol. Chem. 262:8257-8261.

52. Wada, Y., K. Kitamoto, T. Kanbe, K. Tanaka, and Y. Anraku. 1990. SLPI gene of Saccharomyces cerevisiae is essential for vacuolar morphogenesis and function. Mol. Cell. Biol. 10:2214 2223.

53. Walker, J. E., M. Saraste, M. J. Runswick, and N. J. Gay. 1982. Distantly related sequences in the $\alpha$ - and $\beta$-subunits of ATP synthase, myosin, kinases and other ATP-requiring enzymes and a common nucleotide binding fold. EMBO J. 1:945-951.

54. Weisman, L. S., R. Bacallao, and W. Wickner. 1987. Multiple methods of visualizing the yeast vacuole permit evaluation of its morphology and inheritance during the cell cycle. J. Cell Biol. 105:1539-1547.

55. Weisman, L. S., and W. Wickner. 1988. Intervacuole exchange in the yeast zygote: a new pathway in organelle communication. Science 241:589-591.

56. Wilson, D. W., C. A. Wilcox, G. C. Flynn, E. Chen, W.-J. Kuang, W. J. Henzel, M. R. Block, A. Ullrich, and J. E. Rothman. 1989. A fusion protein required for vesicle-mediated transport in both mammalian cells and yeast. Nature (London) 339:355-359. 